\title{
Avaliação da atividade antibacteriana de complexos de prata e cobre com sulfametazina
}

\section{Bianca A. Schimitd*, Mariana M. Quintanilha*, Wilton R. Lustri, Pedro P.Corbi.}

\section{Resumo}

Neste trabalho, foi realizada a síntese de complexos de $\mathrm{Ag}(\mathrm{I})$ e $\mathrm{Cu}(\mathrm{II})$ com sulfametazina. Os complexos foram caracterizados por análise elementar, espectroscopia no infravermelho, análise térmica, ressonância magnética nuclear e espectrometria de massas. A atividade antibacteriana dos complexos foi avaliada pelo ensaio de determinação da concentração inibitória mínima (CIM) e a interação dos compostos com biomoléculas foi analisada por eletroforese.

\section{Palavras-chave:}

Complexos metálicos, sulfonamida, atividade antibacteriana

\section{Introdução}

As sulfonamidas, ou sulfas, constituem o primeiro grupo de agentes quimioterápicos utilizados como antibacterianos. As sulfas são derivadas da p-aminobenzenossulfonamida e possuem em sua fórmula estrutural o grupo $-\mathrm{SO}_{2} \mathrm{NHR}$ [1]. Devido ao crescimento da resistência bacteriana aos antibióticos disponíveis, a busca por fármacos ativos sobre cepas multirresistentes tem sido objeto de pesquisas no mundo todo. Uma estratégia promissora é combinar fármacos consolidados e ativos sobre microrganismos, como as sulfas, e metais com reconhecidas atividades antimicrobianas, tais como 0 cobre e a prata. Esta combinação pode levar a compostos mais ativos sobre microrganismos e com diferentes mecanismos de ação. Neste trabalho, é apresentada a síntese de complexos de $\mathrm{Ag}$ (I) e $\mathrm{Cu}(\mathrm{II}) \mathrm{com}$ sulfametazina ( $\mathrm{SMZ}, \mathrm{C}_{12} \mathrm{H}_{14} \mathrm{~N}_{4} \mathrm{O}_{2} \mathrm{~S}$ ). A SMZ é utilizada na medicina veterinária para o tratamento de infecções respiratórias, gastrointestinais e urinárias $[2,3]$. Os complexos foram caracterizados por análises químicas e espectroscópicas e avaliados quando às atividades antimicrobianas.

\section{Resultados e Discussão}

Os resultados de análise elementar e análise térmica sugerem a composição $\left[\mathrm{Ag}\left(\mathrm{C}_{12} \mathrm{H}_{13} \mathrm{~N}_{4} \mathrm{O}_{2} \mathrm{~S}\right)\right] \cdot 0,5 \mathrm{H}_{2} \mathrm{O}$, para - complexo de prata com SMZ (AgSMZ), e $\left[\mathrm{Cu}\left(\mathrm{C}_{12} \mathrm{H}_{13} \mathrm{~N}_{4} \mathrm{O}_{2} \mathrm{~S}\right)_{2}\right] \cdot 3 \mathrm{H}_{2} \mathrm{O}$ para o complexo de cobre (CuSMZ). Os resultados de espectroscopia no infravermelho (IV) e ressonância magnética nuclear (RMN) sugerem a coordenação da $S M Z$ à prata pelo átomo de nitrogênio do grupo $\mathrm{SO}_{2} \mathrm{~N}$. A atividade antibacteriana do complexo de prata foi confirmada pela determinação dos valores de concentração inibitória mínima (CIM) sobre cepas Gram-positivas (S. aureus e $B$. cereus) e Gram-negativas (E. coli e $P$. aeruginosa). O complexo AgSMZ apresentou valores de CIM de 125 a $250 \mu \mathrm{g} \mathrm{mL}^{-1}$. O complexo de cobre foi ativo apenas sobre a bactéria $P$. aeruginosa com valor de CIM de $500 \mu \mathrm{g} \mathrm{mL}$ 1. Os complexos de $\mathrm{Ag}(\mathrm{I})$ e de $\mathrm{Cu}(\mathrm{II})$ com $\mathrm{SMZ}$ foram analisados quanto a suas atividades de interação com biomoléculas (DNA plasmidial e albumina bovina-BSA). Os resultados mostraram que, nas condições experimentais consideradas, os complexos não interagem com DNA plasmidial ou BSA.

\section{Conclusões}

Foram obtidos complexos de $\mathrm{Ag}(\mathrm{I})$ e $\mathrm{Cu}(\mathrm{II}) \mathrm{com} \mathrm{SMZ}$ de composições $[\mathrm{Ag}(\mathrm{SMZ})] \cdot 0,5 \mathrm{H}_{2} \mathrm{O}$ e $\left[\mathrm{Cu}(\mathrm{SMZ})_{2}\right] \cdot 3 \mathrm{H}_{2} \mathrm{O}$. As análises por IV e RMN indicam que a coordenação do ligante aos metais ocorre pelo nitrogênio do grupo $\mathrm{SO}_{2}-\mathrm{N}$. Os ensaios de atividade antibacteriana mostraram que o complexo AgSMZ é ativo sobre todas as cepas bacterianas testadas, enquanto o complexo CuSMZ é ativo apenas para $P$. aeruginosa. Nenhum dos complexos apresentou interação com o DNA plasmidial ou BSA nos ensaios de eletroforese.

\section{Agradecimentos}

As bolsistas agradecem à FAPESP (processos 2018/12062-4, 2018/09860-6 e 2018/09856-9) pelo auxílio financeiro durante a realização do projeto.

\footnotetext{
${ }^{1}$ Carvalho, W. A. Penildon, S. Farmacologia. $7^{\circ}$ ed. Rio de Janeiro: Guanabara Koogan (2006). 102, 1008-1021

2 Neelofar, N., Ali, N., Khan, A., Amir, S., A. Khan, N., Bilal, M. (2018) Bulletin of the Chemical Society of Ethiopia, 31(3), 445

${ }^{3}$ Mansour, A. M. (2013). Inorganica Chimica Acta, 394, 436-445.
} 